\title{
ECHOCARDIOGRAPHIC FOLLOW UP AFTER SURGICAL CORRECTION OF AORTIC COARCTATION DURING THE FIRST YEAR OF LIFE
}

\author{
Elīna Ligere*, Inguna Lubaua**, Inga Lāce *, Inta Bergmane*, Vita Knauere*, \\ Valts Ozolinšs*, Lauris Šmits*, Normunds Sikora*, and Aris Lācis* \\ * Clinic for Pediatric Cardiology and Cardiac Surgery, University Hospital for Children, Vienības iela 45, Rīga, LV-1004, LATVIA; \\ eteivane@inbox.Iv \\ ** Department of Pediatrics, Rīga Stradiṇš University, Dzirciema iela 16, Rīga, LV-1007, LATVIA
}

Communicted by Vladimirs Kasjanovs

\begin{abstract}
Coarctation of the aorta (AoCo) accounts for $6-10 \%$ of congenital heart diseases in infants. We analysed echocardiographic findings of patients operated on for AoCo in the University Hospital for Children in Riga during the first year of life to evaluate the long-term findings. Fifty-nine children underwent surgical correction of AoCo at the age of $55 \pm 61$ days. The methods of surgical correction were anastomosis end-to-end (ETE) in 29\% ( $n=17)$, subclavian flap aortoplasty (SFA) in $64 \%(n=38)$ and extended anastomosis end-to-end (EETE) in $7 \%(n=4)$. Recoarctation developed in 15 patients (25\%) with no difference between surgical techniques ( $\mathrm{P}>0.05)$. The recoarcation patients had left ventricle hypertrophy (left ventricle mass index ( $L V M i) 76 \pm 19 \mathrm{~g} / \mathrm{m}^{2.7}$ ) normalising after angioplasty ( $L V M i 42 \pm 7 \mathrm{~g} / \mathrm{m}^{2.7}$ ). Patients with recoarctation had a decreased pulsed wave $(P W)$ Doppler systolic/diastolic ratio in abdominal aorta $2.3 \pm 0.4$ versus patients without recoarctation $5.3 \pm 1.2$ and the control group $6.3 \pm 1.4(\mathrm{P}<0.05)$. A high incidence of recoarctation exists in patients operated on for AoCo as small infants. Life-long surveillance is required to monitor and to intervene in a timely way. Supplementation of the echocardiographic protocol with an evaluation of PW Doppler flow pattern in abdominal aorta can provide additional information about the presence of obstruction.
\end{abstract}

Key words: infants, coarctation, echocardiography, recoarctation.

\section{INTRODUCTION}

The incidence of congenital heart diseases (CHD) is $8-12$ per 1000 live born infants (Hofman et al., 2002). Coarctation of the aorta (AoCo), narrowing of the descending aorta usually just distal to the origin of the left subclavian artery, is a relatively common congenital heart disease. It accounts for 6-10\% of CHD (Lindinger et al., 2010) with prevalence approximately 3.6 (2.9-4.9)/10.000 newborn infants (Anonymous, 2011b). Surgical correction is the gold standard for the treatment of AoCo in neonates and small infants due to a lower incidence of recoarctation in comparison to balloon angioplasty in this age group. Recurrent AoCo is treated using balloon angioplasty and stent implantation in older children (Walhout et al., 2004; Peres et al., 2010; Fruh et al., 2011). Despite successful surgical correction in infancy, there is a high risk of development of recoarctation (up to 20-40\%) and arterial hypertension (7-33\%) (Rosenthal, 2005; Hager et al., 2009). Echocardiography in combination with clinical examination is used to evaluate the need for further intervention. The Clinic for Pediatric Cardiology and Cardiac Surgery of the University Hospital for Children in Riga is the only institution in Latvia where congenital heart diseases are treated and followed up. The beginning of surgical correction of AoCo in Latvia dates back to 1964 (Volkolakov and Lacis, 1987). Balloon angioplasty of Ao recoarctation and primary AoCo in older children was started in January, 2009. We analysed the echocardiographic findings of patients operated on due to AoCo within the first year of life during the years 2000-2010 and who survived up to 31 January 2011, to evaluate the long-term findings in comparison with preoperative data. This is the first echocardiographic study in Latvia that examines findings of patients with AoCo operated on as neonates and small infants.

\section{MATERIALS AND METHODS}

Study patients. From the database of the Clinic for Pediatric Cardiology and Cardiac Surgery of University Hospital 
in Rīga, Latvia we selected all patients who within the period of time from 1 January 2000 to 31 December 2010 had undergone surgical correction of AoCo through the left thoracotomy at the age up to 12 months $(n=73)$. There were 13 cases of early or late death. From the remaining 60 patients, in 59 cases the parents agreed for their child to be included in the study and further analyzed.

The study was approved by the Committee of Ethics of the University Hospital for Children in Rìga, Latvia.

During the period of time from January, 2009 to 31 December 2011, 15 patients were admitted to the hospital due to recoarctation and underwent balloon angioplasty. All $(\mathrm{n}=$ 59) patients were repeatedly examined up to the end of the study period in 31 December 2011. The echocardiographic data from the end of the study period were compared with the preoperative data and an age-matched healthy control group ( 28 children, $\mathrm{n}=17$ boys, $\mathrm{n}=11$ girls). We also examined measurements prior to balloon angioplasty for those who had developed recoarctation.

Echocardiographic examination. All of the patients underwent a complete 2-dimensional, M-mode, colour flow Doppler and spectral Doppler examination. All recorded measurements were made according to our standard protocol. To access the cardiac anatomy and function, examinations in the following projections were made: subcostal long and short axis, apical, parasternal long and short axis and suprasternal views. Examinations were performed using commercially available ultrasound systems. Retrospective review of recordings made with an Accuson Aspen and Hewlett Packard Sonos 4500 and prospective echocardiographic examinations with a Philips iE33 and Philips HD11XE were carried out. The retrospective echocardiography recordings were used to analyze preoperative data for the patients operated on during 2000-2008. M-mode measurements were made from a parasternal long axis view at the level of the tips of the papillary muscles with the placement of a M-mode cursor guided by 2-dimensional imaging, and using the leading edge to leading edge technique. The transverse aortic arch was measured in the suprasternal long axis as the maximum systolic dimension between the innominate and left common carotid arteries (Pettersen et al., 2008). The vessels were measured perpendicular to the long axis in maximum expansion during systole. The measurements of cardiovascular structures were expressed as $\mathrm{Z}$ scores using the Haycock formula to calculate the body surface area (BSA) (Lopez et al., 2010). The left ventricle (LV) mass was calculated from M-mode measurements using the formula of Devereux et al. (Kervancioglu et al., 2011). Left ventricle mass was indexed to height ${ }^{2.7}$ (LVMi) (Foster et al., 2008). The prospective measurements (during the follow up and balloon angioplasty of Ao recoarctation) were supplemented with pulsed wave (PW) Dopplerographic flow measurements in the abdominal Ao at the level of the diaphragm in parasagital view and included maximum systolic velocity (PW S) and minimum diastolic forward flow velocity (PW D) $(\mathrm{m} / \mathrm{s})$. The systolic to diastolic velocity ratio was derived from the maximum forward sys-

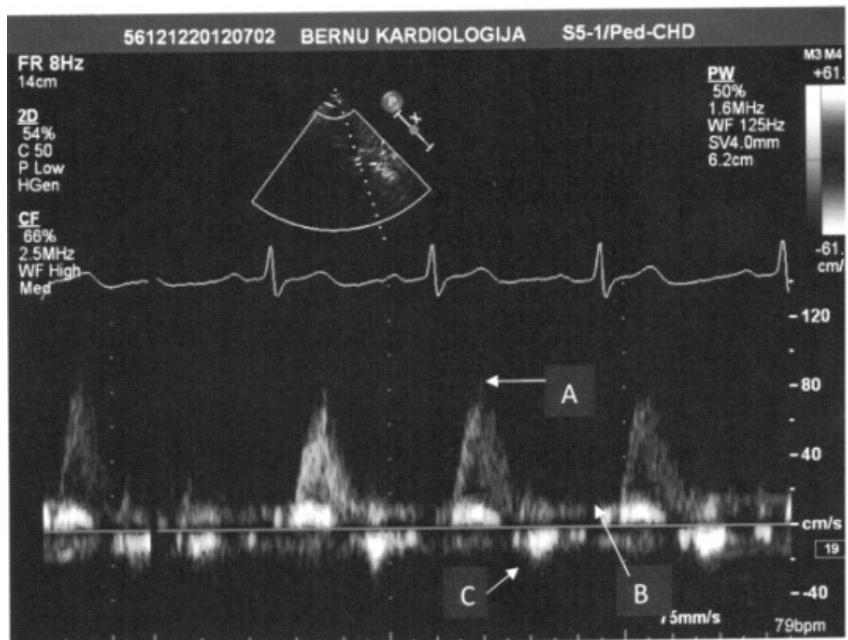

Fig. 1. Pulsed wave Dopplerographic flow pattern in abdominal aorta in a patient without recoarctation (A, maximum systolic forward flow; B, minimum diastolic forward flow; $\mathrm{C}$, early diastolic reversal).

tolic flow velocity divided by the minimum diastolic forward flow velocity (Fig.1). Recoarctation was defined as a blood pressure gradient of pressure between the upper and lower limb $\geq 20 \mathrm{mmHg}$ or a peak instantaneous Doppler gradient $\left(4 \mathrm{xV}_{\max }^{2}\right)>25 \mathrm{mmHg}$.

Statistical methods. The Microsoft Office Excel 2003 software was used for data storage and processing. We used statistical software SPSS 16.0 for Windows (SPSS 16.0, SPSS Inc., Chicago, IL, USA) for statistical analysis. The results of the measurements were expressed as means and standard deviations. The t-test was used to compare the means from two samples. ANOVA was used to compare means between three groups. The Pearson's chi-square test and Fisher's exact tests were used to compare categorical variables of the groups of patients. The $P$ value $<0.05$ was considered statistically significant.

\section{RESULTS}

A long-term echocardiographic follow-up was carried out in 35 boys $(59 \%)$ and 24 girls $(41 \%)$ who were operated on as neonates in $46 \%(\mathrm{n}=27)$ of the cases, and as infants in $54 \%$ $(n=32)$ of the cases. The methods of surgical correction were anastomosis end-to-end (ETE) in 29\% $(n=17)$, extended anastomosis end-to-end (EETE) in 7\% ( $\mathrm{n}=4)$ and subclavian flap aortoplasty (SFA) in $64 \%(\mathrm{n}=38)$. The characteristics of the patients at the time of primary correction are given in Table 1 . The continuous wave Doppler gradient (CW Pg max.) in descending Ao was $62 \pm 23 \mathrm{~mm}$ $\mathrm{Hg}$ prior to the surgery. The left ventricle end diastolic dimension (LVEDD) was $20.9 \pm 5.6 \mathrm{~mm}$; interventricular septal end diastolic dimension (IVSd) was $6.36 \pm 1.48 \mathrm{~mm}$ and left ventricular end diastolic posterior wall dimension (LVPWd) $4.8 \pm 1.2 \mathrm{~mm}$. Twenty-one of 59 patients $(36 \%)$ had concomitant intracardiac pathologies (Table 2). Only seven patients $(12 \%)$ had a bicuspid Ao valve. The left ventricle mass (LVM) prior to surgery was $20.8 \pm 11.4 \mathrm{~g}$ (measured in patients without aortic stenosis (AoS), mitral stenosis (MS), pulmonary stenosis $(\mathrm{PS}), \mathrm{n}=49$ ) and $59 \%$ of the 
Table 1

CHARACTERISTICS OF PATIENTS AT THE TIME OF PRIMARY SURGICAL CORRECTION OF COARCTATION OF THE AORTA $(\mathrm{N}=$ 59)

\begin{tabular}{l|c|c|cc}
\hline \multicolumn{1}{c|}{ Parameter } & Mean & \multirow{2}{*}{$\begin{array}{c}\text { Standard } \\
\text { deviation }\end{array}$} & \multicolumn{2}{|c}{ 95\%CI } \\
\cline { 4 - 5 } & & Minimum & Maximum \\
\hline $\begin{array}{l}\text { Age at the time of surgery } \\
\text { (days) }\end{array}$ & 55.37 & \pm 61.34 & 2 & 243 \\
Weight $(\mathrm{kg})$ & & & & \\
Height $(\mathrm{cm})$ & 4.41 & \pm 1.74 & 1.7 & 9.6 \\
Body surface area $\left(\mathrm{m}^{2}\right)$ & 55.75 & \pm 6.40 & 45 & 76 \\
& 0.26 & \pm 0.07 & 0.15 & 0.46
\end{tabular}

Table 2

CONCOMITANT INTRACARDIAC PATHOLOGIES IN PATIENTS $(\mathrm{N}=59)$ FOLLOWED UP

\begin{tabular}{l|c}
\hline Concomitant intracardiac pathology & Count (\% of all 59 patients) \\
\hline Ventricular septal defect (VSD): & $10(17)$ \\
Perimembranous VSD & $7(12)$ \\
Muscular VSD & $3(5)$ \\
Atrial septal defect (ASD) (significant) & $1(2)$ \\
Aortic stenosis (AoS) & $7(12)$ \\
Valvular AoS & $3(5)$ \\
Subvalvular AoS & $3(5)$ \\
Supravalvular AoS & $1(2)$ \\
Pulmonary stenosis (PS) + ASD & $1(2)$ \\
Mitral valve pathology & $1(2)$ \\
Mitral stenosis (MS) + VSD & $1(2)$
\end{tabular}

patients had LVM above the 95th percentile. The size of the transverse aortic arch was $7.31 \pm 1.55 \mathrm{~mm}$ (95\%CI 6.88$7.73 \mathrm{~mm})$. There were eight cases $(13 \%)$ of hypoplastic transverse arch $(\mathrm{z}$ value $\leq-2)$. The patients with AoCo and VSD had smaller transverse arches than those with isolated AoCo $(6.55 \pm 1.45 \mathrm{~mm}$ versus $7.68 \pm 1.45 \mathrm{~mm}, P=0.036)$. The transverse arch in the patients who had undergone ETE was $8.14 \pm 1.82 \mathrm{~mm}$, in the cases of SFA $-7.03 \pm 1.35$ $\mathrm{mm}(P=0.022$, ETE versus SFA $)$, and $6.67 \pm 1.53 \mathrm{~mm}$ in the cases of EETE ( $P=0.65$, SFA versus EETE). Prior to surgery, $17 \%(n=10)$ of the patients had decreased left ventricle systolic function with an ejection fraction (EF) below 55\%. Following the operation, the $\mathrm{CW}$ Pg maximum in the descending aorta was $19 \pm 9 \mathrm{~mm} \mathrm{Hg}$. Only one patient had decreased left ventricle EF. All the patients were considered to have complete surgical correction of the lesion without significant residual gradient and without hypertension on the upper extremities.

The patients were followed up for $70.68 \pm 33.37$ months (one year and six months to 11 years). During the study period, ten patients were in need of surgical repair of concomitant intracardiac pathology at the age of $21 \pm 14$ months. Freedom from the need for intracardiac repair was observed in $84.7 \%$ (95\% CI - 107.45-129.65 months). Balloon angioplasty of Ao recoarctation was commenced at the University Hospital for Children on January, 2009. Recoarctation was observed in 15 patients $(25 \%)$ in the study group. The cumulative survival without recoarctation during the study period was $74.6 \%$ (95\% CI 89.56-118.07 months)
(Fig. 2). The patient age at the time of angioplasty was $35.67 \pm 33.68$ months (two months to eight years). Before the balloon angioplasty $\mathrm{CW} \mathrm{Pg} \mathrm{maximum} \mathrm{in} \mathrm{descending} \mathrm{Ao}$ was $78 \pm 19 \mathrm{~mm} \mathrm{Hg}$ with a diastolic forward flow (Fig. 3).

The echocardiographic findings at the time of recoarctation and the end of the follow-up period in comparison with an age matched healthy control group are given in Table 3.

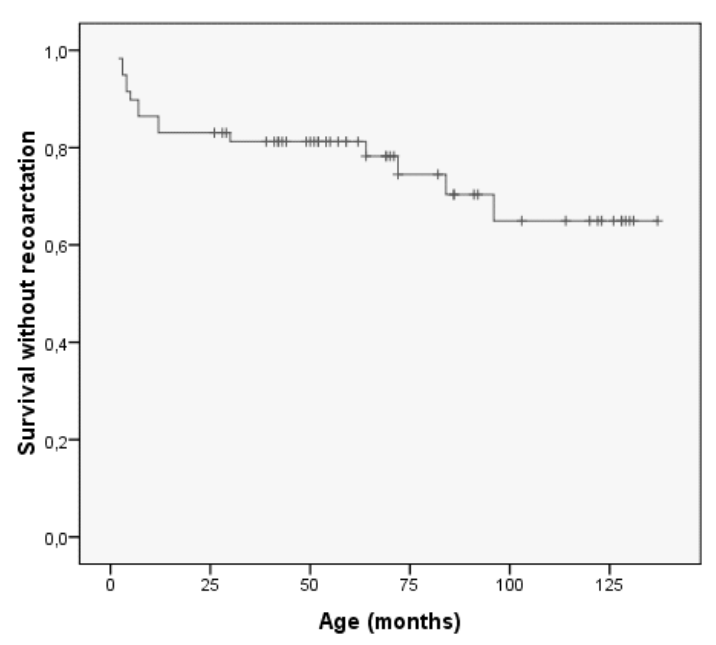

Fig. 2. Cumulative survival without recoarctation during the study period.
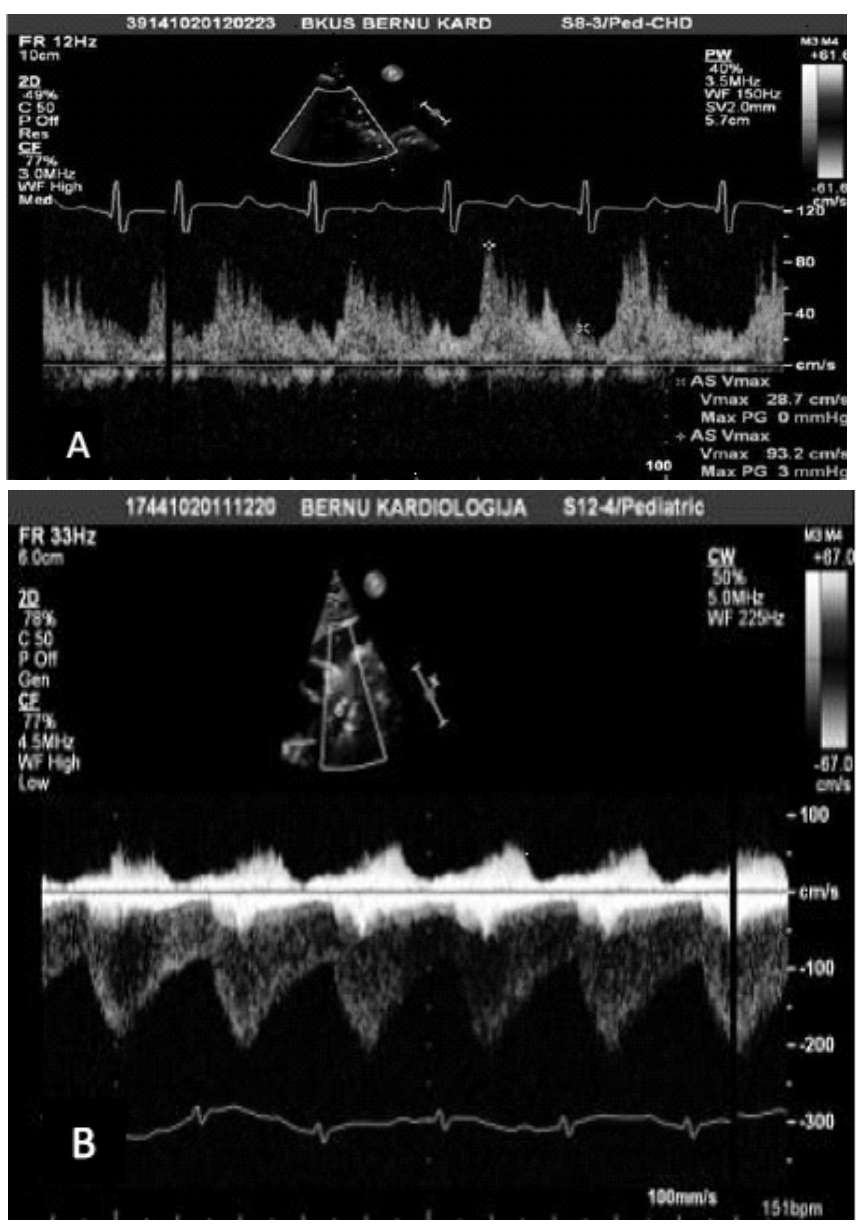

Fig. 3. A 3-month-old infant with Ao recoarctation: A, pulsed wave (PW) Doppler flow pattern in abdominal Ao- pulsed wave systolic/diastolic ratio ( PWS/D) 3.2; B, continuous wave Doppler flow in descending Ao (high gradient with diastolic forward flow). 
COMPARISON OF LEFT VENTRICLE MASS ( LVM), LEFT VENTRICLE MASS INDEX (LVMI) AND PULSED WAVE (PW) DOPPLEROGRAPHIC FINDINGS BETWEEN THE STUDY GROUP AT THE TIME OF RECOARCTATION, THE END OF THE STUDY, AND THE CONTROL GROUP

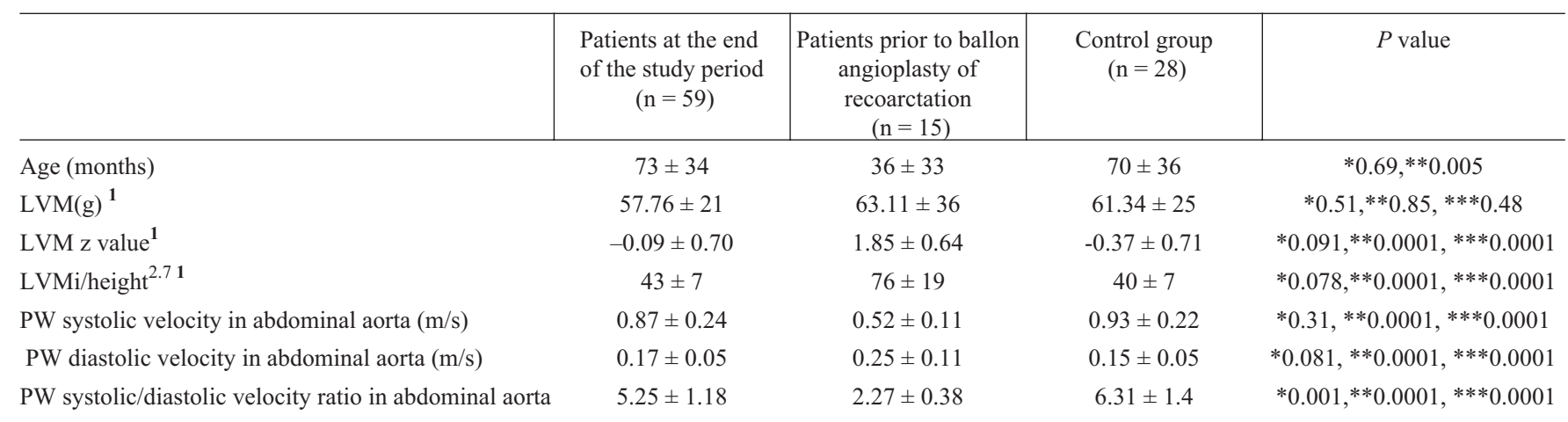

\footnotetext{
* Comparison between the control group and patients at the end of the study (t-test)

** Comparison between the control group and patients with recoarctation prior to balloon angioplasty (t-test)

*** Comparison between patients at the end of the study and patients with recoarctation prior to balloon angioplasty (t-test)

${ }^{1}$ LVM, LVM z values, LVMi/height ${ }^{2,7}$ in the study group calculated for the patients without aortic stenosis and mitral valve pathology $(\mathrm{n}=49)$
}

At the end of the study, the patient CW Pg max. in descending Ao was $20 \pm 9 \mathrm{~mm} \mathrm{Hg}(95 \% \mathrm{CI} 17.6-22.4 \mathrm{~mm} \mathrm{Hg})$, and no patient was in need of current reintervention. The LVMi/height ${ }^{2,7}$ for the study patients was $42.49 \pm 7.07$, median 42.25 (95\% CI 40.39-44.59), while in the control group it was $39.47 \pm 7.04$, median $40.35(95 \%$ CI 36.74-42.20), and for patients with a recoarctation prior to balloon angioplasty $-76.32 \pm 19.88$, median $71.70(95 \%$ CI 65.31-87.33). At the end of the study period the left ventricle mass index remained higher for the patients with recoarctation $\left(45.67 \pm 6.53 \mathrm{~g} / \mathrm{m}^{2,7}\right)$ versus in patients without recoarctation $\left(41.63 \pm 6.56 \mathrm{~g} / \mathrm{m}^{2,7}\right)$ and the control group $\left(39.47 \pm 7.04 \mathrm{~g} / \mathrm{m}^{2,7}\right)(P=0.019)$. However, there were no significant differences in LVM z values $(P=0.087)$.

The period of time from the balloon angioplasty and the end of the study was $21.07 \pm 8.32$ months. The Ao transverse arch in the study group was $12.43 \pm 1.81 \mathrm{~mm}$, and $13.36 \pm$ $1.98 \mathrm{~mm}$ in the control group $(P=0.029 \mathrm{~mm})$. The Ao transverse arch $\mathrm{z}$ value in the study group was $-0.93 \pm 0.74$ and $-0.69 \pm 0.55$ in the control group $(P=0.137)$. There were no significant differences between the Ao transverse arch sizes between the methods of correction: anastomosis ETE $12.38 \pm 2.34 \mathrm{~mm}$, SFA $12.35 \pm 1.68 \mathrm{~mm}$ and EETE $13.25 \pm 1.26 \mathrm{~mm}(P=0.652)$. The size of the Ao isthmus in the study group was $9.31 \pm 1.55 \mathrm{~mm}$, and in the control group $-11.45 \pm 2.06 \mathrm{~mm}(P=0.0001)$. The Ao isthmus $\mathrm{z}$ value for the study group patients was $-0.74 \pm 0.76$ versus $0.01 \pm 0.67$ for the control group $(P=0.0001)$.

\section{DISCUSSION}

Our study included a relatively small number of patients, as the birth rate in Latvia within the years 2000-2010 was only $21197 \pm 1212$ live born infants per year (Anonymous, 2011a). The prevalence of AoCo in Latvia during those years was $3.4 \pm 1.2$ per 10000 live born infants per year

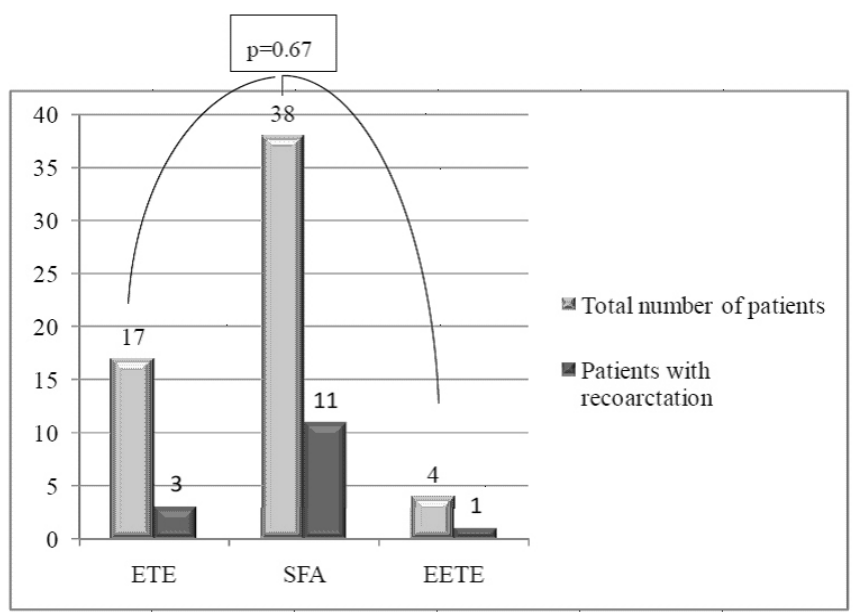

Fig. 4. The incidence of recoarctation of the aorta in relation to the surgical technique of primary correction of coarctation: anastomosis end-to-end (ETE), subclavian flap aortoplasty (SFA) and extended anastomosis end-to-end (EETE).

(Ligere et al., 2011). There was a relatively high incidence of Ao recoarctation. Data from the literature indicates a recoarctation rate for the patients operated as neonates and small infants of 7-29\% (Sudarshan et al., 2006; Burch et al., 2009; Hager et al., 2009; Kaushal et al., 2009; Fruh et al., 2011). There were no statistically significant differences between the incidence of recoarctation and the surgical technique (Fig. 4), but there was a prevalence of subclavian flap angioplasties used in small infants during the study period. More than one half of patients experienced recoarctation within a year following primary surgery, which was connected with intensive somatic growth and scarring processes. Kaushal et al. (2009) described $75 \%$ of recoarctations to occur within the first year of life. At the time of primary diagnosis and recoarctation, the patients showed hypertrophy of the left ventricle, which gradually decreased after relief of stenosis, but LVMi remained higher in com- 
parison with the patients without recoarctation and the control group at the end of the study. Authors give different cut-off values to define left ventricle (LV) hypertrophy in children and adolescents. LV hypertrophy in adults is considered as LV Mi/heigh ${ }^{2,7} 51 \mathrm{~g} / \mathrm{m}^{2,7}$ (De Simone et al., 1995). Foster et al. (2008) observed the same level as the $95^{\text {th }}$ percentile for healthy children. Daniels SR et al. (1995) reported $38.6 \mathrm{~g} / \mathrm{m}^{2.7}$ as the $95^{\text {th }}$ percentile for a healthy pediatric population. Khoury et al. (2009) found that for patients years old, LVMi/heigh ${ }^{2.7}$ varied with age and percentiles for newborns and infants were approximately double the levels for older children and adolescents: the $95^{\text {th }}$ percentile ranged from $80 \mathrm{~g} / \mathrm{m}^{2.7}$ for newborns to $40 \mathrm{~g} / \mathrm{m}^{2.7}$ for 11-year-old children. Left ventricle hypertrophy together with arterial hypertension is a cardiovascular risk factor that increases risk of myocardial infarction, stroke, and death and can be modified (Bauml, 2010). Small infants should be followed up frequently following the surgical correction to exclude the development of recoarctation and a need for reintervention.

The echocardiographic protocol for the follow up of the study group and the control group was supplemented by an analysis of abdominal aortic PW Doppler flows. Echocardiography has become the primary non-invasive modality used in the assessment of AoCo and recoarctation. Clinical stratification of the severity of AoCo is based on the Ao pressure gradient, clinical symptoms, and the degree of luminal narrowing. Suboptimal alignment of the CW Doppler beam with the flow jet may lead to an underestimation of the severity of recoarctation. Analysis of abdominal PW Doppler patterns by Silvilairat et al. (2008) showed the systolic to diastolic velocity ratio (PW S/D) $<3.6$ to be a predictor of clinical coarctation status. In our study, PW S/D ratios were markedly decreased in those having clinically significant recoarctation $(<0.05)$, which is consistent with these data. Also, the presence of early diastolic reversal flow indicates the absence of significant recoarctation. Pulsed wave Doppler signals in the abdominal Ao at the level of diaphragm are easy to obtain and serve as additional information to CW Doppler flow prophile in descending Ao to confirm the recoarctation. Additional studies to analyse more quantitative Ao PW Doppler parameters such as pulsatility index and pulse delay in our patients are required.

The decision on the type and timing of surgical intervention or reintervention often rely on detailed measurements of cardiac structures. Liu et al. (2010) found no correlation between the size of the proximal Ao arch at the last follow up and its size before the repair or the technique used, and one-third of the patients in their study had a small proximal arch at both times. In our study, the mean $z$ values of the proximal transverse arch at the end of the study did not statistically differ from the control group, but there were still five patients $(9 \%)$ with a $\mathrm{z}$ score of $-2.28 \pm 0.15$ in the study group with $\mathrm{CW} \mathrm{Pg}$ maximum of $15.2 \pm 5.8 \mathrm{~mm} \mathrm{Hg}$. Four of these patients had undergone SFA, and one had anastomosis ETE. These patients had no arterial hypertension at the end of the study, but they might be at risk of developing hypertension in the future. There were no transverse arch $\mathrm{z}$ values of -2 or below for the control group patients. There might be differences between the surgical techniques and the surgeons in the capacity to enlarge the transverse Ao arch. We need additional further studies to determine whether such patients might be better operated on through sternotomy with extended arch repair, because remodelling of the hypoplastic proximal transverse arch might not occur after conventional coarctation repair in patients with moderately hypoplastic proximal transverse arches.

Our data showed a significantly smaller isthmus in the study group patients in the absence of clinically significant recoarctation, in comparison with controls $(P=0.0001)$. Puranik et al. (2009) in magnetic resonance (MR) surveillance 20 years following AoCo correction at the age up to two years detected significant rates of recoarctation $(34 \%$ of mild and 34\% moderate to severe recoarctations). They suggested more frequent non-invasive surveillance with clinical examination plus MR as the most cost-effective method for these patients.

Future research might be addressed towards prolongation of the follow-up period to obtain more data about the longterm outcomes and the changes in the measured parameters for these patients entering adolescence and adulthood.

In conclusion, there is a high incidence of recoarctation in patients operated on due to AoCo as neonates and small infants. Life-long surveillance of these patients is required to monitor and intervene in a timely way when necessary. Supplementation of the echocardiographic protocol with an evaluation of PW Doppler flow pattern in the abdominal aorta can provide additional information about the presence of obstruction.

\section{REFERENCES}

Anonymous (2011a). Central Statistical Bureau of Latvia www.csp.gov.lv/statistika-temas/iedzivotaji-galvenie-raditaji (last accessed 4 February 2011).

Anonymous (2011b). European surveillance of congenital anomalies. http:// www.eurocat-network.eu/prevdata/results (last accessed 10 March 2011).

Bauml, M. (2010). Left ventricular hypertrophy: An overlooked cardiovascular risk factor. Cleve. Clin. J. Med., 77 (6), 381-387.

Burch, F., Cowley, C.G., Holubkov, R., Null, D., Lambert, L., Kouretas, P. C. (2009). Coarctation repair in neonates and young infants: Is small size or low weight a risk factor? J. Thorac. Cardiovasc. Surg., 138, 547-552.

Daiels, S. R., Kimball, T. R., Morrison, J. A., Khoury, P., Meyer, R. A.(1995). Indexing left ventricle mass to account for differences in body size in children and adolescents without cardiovascular disease. Amer. J. Cardiol., 76, 699-701.

De Simone, G., Devereux, R. B., Daniels, S. R., Koren, M. J., Meyer, R. A., Roman, M. J. (1995). Effect of growth on variability of left ventricular mass: Assessment of allometric signals in adults and children and their capacity to predict cardiovascular risk. J. Amer. Coll. Cardiol., 25, 1056-1062.

Fruh, S., Knorsh, W., Dodge-Khatami, A., Dave, H., Petre, R., Kretschmar, O. (2011). Comparison of surgical and interventional therapy of native and recurrent aortic coarctation regarding different age groups during childhood. Eur. J. Cardiothorac. Surg., 39, 989-904. 
Foster, B. J., Mackie, A. S., Mitsnefes, M. (2008). A novel method of expressing left ventricular mass relative to body size in children. Circulation, 117, 2769-2775.

Hager, A., Schreiber, C., Nutzi, S., Hess, J. (2009). Mortality and restenosis rate of surgical coarctation repair in infancy: A study of 191 patients. Cardiology, 112, 36-41.

Hofman, J. I. E., Kaplan, S. (2002).The incidence of congenital heart disease. J. Amer. Coll. Cardiol., 39, 1890-1900.

Kaushal, S., Backer, C. L., Patel, J. N., Patel, S. K., Walker, B. L., Weigel, T. J., Randolph, G., Wax, D., Mavroudis, C. (2009). Coarctation of the aorta: midterm outcomes of resection with extended end-to-end anastomosis. Ann. Thorac. Surg., 88, 1932-1938.

Kervancioglu, P., Kervancioglu, M., Tuncer, M. C., Hatipoglu, E. S. (2011). Left ventricular mass in normal children and its correlation with weight, height and body surface area. Int. J. Morphol., 29 (3), 982-987.

Khoury, P. R., Mitsnefes, M., Daniels, S. R., Kimbal, T. R. (2009). Age specific reference intervals for indexed left ventricular mass in children. $J$. Amer. Soc. Echocardiogr., 22 (6), 709-714.

Ligere, E., Lacis, A., Smits, L., Ozolins, V., Sikora, N., Bergmane, I., Lubaua I., Lace I., Feldmane L. (2011). Aortic coarctation repaired within the first year of life. Acta Chirurgica Latviensis, 11 (2), 98-103.

Lindinger, A., Schwedler, G., Hense, H. W. (2010). Results of PAN Study: Congenital heart defects in newborns in Germany-prevalence and association with demographic, genetic and peripartal parameters. Cardiol. Young., 20 (SuppS2), P S3.

Liu, J. Y. J., Kowalski, R., Jones, B., Konstantinov, I. E., Cheung, M. M. H., Donath, S., Brizard, C. P., d`Udeken, Y. (2010). Moderately hypoplastic arches: Do they reliably grow into adulthood after conventional coarctation repair? Interact. Cardiovasc. Thorac. Surg., 10, 582-586.

Lopez, L., Colan, S. D., Frommelt, P. C., Ensing, G. J., Kendal, K., Younoszai, A., Ensing, G. J., Kendall, K., Younoszai, A. K., Wyman W.
L., Geva, T. (2010). Recommendations for quantification methods during the performance of a pediatric echocardiogram: A report from the Pediatric Measurements Writing Group of the American Society of Echocardiography Pediatric and Congenital Heart Disease Council. J. Amer. Soc. Echocardiogr., 23, 465-495.

Peres, A., Martins, J. D., Parames, F., Gil, R., Matias, C., Franco, J., Freitas, J., Trigo, C., Fragata, J., Pinto F. F. (2010). Isolated coarctation: Experience in 100 consecutive patients. Rev. Port. Cardiol., 29 (1), 23-35.

Pettersen, M. D., Du, W., Skeens, M. E., Humes, R. A. (2008). Regression equotions for calculation of $\mathrm{Z}$ scores of cardiac structures in a large cohort of healthy infants, children, and adolescents: An echocardiographic study. J. Amer. Soc. Echocardiogr., 21, 922-934.

Puranik, R., Tsang, V. T., Puranik, S., Jones, R., Cullen, S., Bonhoeffer, P., Hughes, M. L., Taylor, A. M. (2009). Late magnetic resonance surveillance of repaired coarctation of the aorta. Eur. J. Cardiothorac. Surg., 36 (1-3), 91-95.

Rosenthal, E. (2005). Coarctation of the aorta from fetus to adult: Curable condition or lifelong disease process? Heart, 91 (11), 1495-1502.

Silvilairat, S., Cetta, F., Biliciler-Denktas, G., Ammash, N. M., Cabalka, A. K., Hagler, D., O'Leary, P. W. (2008). Abdominal aortic pulsed wave Doppler patterns reliably reflect clinical severity in patients with coarctation of the aorta. Congenit. Heart Dis., 3, 422-430.

Sudarshan, C. D., Cochrane, A. D., Jun, Z. H., Soto, R., Brizard, C. P. (2006). Ann. Thorac. Surg., 82, 158-163.

Walhout, R. J., Lekkerkerker, J. C., Oron, G. H., Bennink, G. B. W. E., Meijboom, E. J. (2004). Comparison of surgical repair with balloon angioplasty for native coarctation in patients from 3 months to 16 years of age. Eur. J. Cardiothorac. Surg., 25, 722-727.

Volkolakov, Ya. V., Lacis, A. T. (1987). Diagnosis and methods of surgical treatment of coarctation of the aorta in early childhood. Грудная хирургия, Москва. № 2, 7-12 (in Russian).

Received 18 December 2012

\section{EHOKARDIOGRĀFISKS NOVĒRTĒJUMS PACIENTIEM AR ĶIRURĢISKI KORIĢĒTU AORTAS KOARKTĀCIJU PIRMAJĀ DZĪVES GADĀ}

Aortas koarktācija (AoKo) veido 6-10\% no iedzimtajām sirdskaitēm zīdainiem. Analizējām ehokardiogrāfijas atradi pacientiem, kuriem Bērnu klīniskās universitātes slimnīcas Bērnu kardiolog̣ijas un kardioķirurǵijas klīnikā pirmajā dzīves gadā veikta ķirurğiska aortas koarktācijas korekcija, lai noskaidrotu ilgtermiṇa rezultātus. Analizēti 59 bērni, kuriem AoKo kirurğiska korekcija veikta $55 \pm 61$ dienu vecumā. Ķirurğiskas korekcijas metodes bija anastomoze gals-galā $29 \%(\mathrm{n}=17)$, ielāps ar kreisās zematslēgas artērijas lēveru 64\% (n = 38) un pagarināta anastomoze gals-galā 7\% ( $\mathrm{n}=4)$. Rekoarktācija attīstījās 15 pacientiem $(25 \%)$, un netika novērotas atškirības dažādu kirurğisku metožu starpā $(P>0.05)$. Rekoarktācijas brīdī pacientiem novēroja būtisku kreisā kambara hipertrofiju (kreisā kambara masas indekss $\left.(L V M i) 76 \pm 19 \mathrm{~g} / \mathrm{m}^{2,7}\right)$, kas mazinājās pēc balonangioplastijas ( $L V M i 42 \pm 7 \mathrm{~g} / \mathrm{m}^{2,7}$ ). Pacientiem ar rekoarktāciju bija pazemināta pulsa viḷna (PV) doplerogrāfiska sisitoliskas/diastoliskas plūsmas attiecība vēdera aortā 2,27 $\pm 0,38$ salīdzinājumā ar pacientiem bez rekoarktācijas 5,25 $\pm 1,18$ un kontroles grupu 6,31 $\pm 1,41(P<0,05)$. Pacientiem ar agrīnā vecumā kirurğiski koriǵētu koarktāciju bija augsta rekoarktācijas incidence. Nepieciešama novērošana visa mūža garumā savlaicīgai komplikāciju diagnosticēšanai un ārstěšanai. Ehokardiogrāfijas protokola papildināšana ar PV doplerogrāfiskiem mērījumiem vēdera aortā sniedz papildus informāciju par aortas obstrukciju pacientiem pēc koarktācijas korekcijas. 